\title{
Ileal digestibility and endogenous flow of minerals and amino acids: responses to dietary phytic acid in piglets
}

\author{
Tofuko A. Woyengo ${ }^{1}$, Aaron J. Cowieson ${ }^{2}$, Olayiwola Adeola ${ }^{3}$ and Charles M. Nyachoti ${ }^{1}$ * \\ ${ }^{1}$ Department of Animal Science, University of Manitoba, Winnipeg, MB R3T 2N2, Canada \\ ${ }^{2}$ Danisco (UK) Limited, Marlborough SN8 IAA, UK \\ ${ }^{3}$ Department of Animal Science, Purdue University, West Lafayette, IN 47907-2054, USA
}

(Received 26 August 2008 - Revised 12 November 2008 - Accepted 18 November 2008 - First published online 15 January 2009)

Effects of phytic acid (PA) on ileal mineral and amino acid (AA) digestibilities and ileal endogenous AA flow in piglets were investigated. Seven ileal-cannulated weanling pigs were fed a casein-maize starch-based diet with PA (as sodium phytate) at $0,5,10 \mathrm{or} 20 \mathrm{~g} / \mathrm{kg}$ in $4 \times 4 \mathrm{Latin}$ square design with three added columns to give seven observations per treatment. The basal diet was formulated to meet National Research Council energy and AA requirements for piglets. The respective digestibility and endogenous lysine loss were determined by indicator and homoarginine methods. The apparent ileal digestibility (AID) of Na, K and $\mathrm{P}$ was linearly and quadratically reduced $(P<0.05)$ by increased dietary PA concentration, whereas that of $\mathrm{Ca}$ and $\mathrm{Mg}$ was only linearly reduced $(P<0.05)$ by the dietary PA. The AID values for Mg and $\mathrm{Na}$ were negative $(-0.03$ and $-0 \cdot 18$, respectively) when PA was supplemented at $20 \mathrm{~g} / \mathrm{kg}$. The AID of isoleucine, leucine and valine responded quadratically to dietary PA concentration, though the differences between the AID values of the AA due to change in dietary PA concentration were marginal (at most by 1.8 percentage units). Furthermore, dietary PA did not affect $(P>0.05)$ endogenous AA losses. The results suggest that PA has limited effect on the digestibility and endogenous losses of AA in piglets, but can reduce AID of $\mathrm{Mg}$ and Na partly by increasing endogenous losses of these minerals as evidenced by their negative AID values.

Endogenous mineral and amino acid flow: Mineral and amino acid digestibility: Phytic acid: Piglets: Terminal ileum

Phytic acid (PA; myo-inositol hexaphosphate) is a constituent of plant seeds, where it serves as a storage form of $\mathrm{P}^{(1)}$. Plant seeds form the bulk of pig and poultry feeds. PAbound $\mathrm{P}$ in plant seeds (except in viscous grains like rye and wheat, which have high endogenous phytase activity) is, however, poorly digested by pigs and poultry because they do not produce sufficient amount of phytase enzyme that hydrolyses $\mathrm{PA}^{(2)}$.

Furthermore, each of the six phosphate groups on PA has two protons, which can dissociate to leave PA with twelve negative charges and hence the potential to bind positively charged molecules such as minerals and basic amino acids $(\mathrm{AA})^{(1)}$. Of the twelve protons on PA, six can dissociate at acidic $\mathrm{pH}$, three at neutral $\mathrm{pH}$ and the remaining three at basic $\mathrm{pH}$, suggesting that PA has capacity to bind positively charged molecules in diet and endogenous gastrointestinal secretions such as digestive enzymes and mucin at all $\mathrm{pH}$ conditions found in the gut $^{(1)}$.

PA has indeed been reported to limit the digestibility of minerals and AA in boilers ${ }^{(3-5)}$, which implies reduced efficiency of nutrient utilisation and increased environmental discharge of nutrients as a result of excessive excretion of unabsorbed nutrients due to $\mathrm{PA}^{(6)}$. PA has also been shown to increase endogenous losses of minerals and AA in broilers ${ }^{(7,8)}$. Because the increased endogenous nutrient losses in the gut are associated with increased maintenance requirement for the lost nutrients and of the energy spent on their secretion ${ }^{(9)}$, an increase in endogenous losses of nutrients due to PA imply that there are other adverse effects of PA on efficiency of nutrient utilisation in addition to reducing nutrient digestibility. However, there is a lack of information on the effect of PA on endogenous nutrient losses in pigs. Furthermore, the effect of PA on digestibility of nutrients, especially AA, has been variable. For instance, Bohlke et al. ${ }^{(10)}$ and Liao et al. ${ }^{(11)}$ reported a reduction in AA digestibility in pigs due to PA, whereas Johnston et al. ${ }^{(12)}$ and Woyengo et al. ${ }^{(13)}$ did not report improvement in AA digestibility due to phytase (which hydrolyses PA) despite increased PA hydrolysis as evidenced by improved $\mathrm{P}$ digestibility in their studies. The objective of the present study was to determine the effect of PA on the ileal mineral and AA digestibilities and endogenous flow of AA at the terminal ileum of weanling pigs.

\section{Materials and methods}

\section{Animals}

Seven Genesus (Yorkshire-Landrace female $\times$ Duroc male) barrows (mean initial body weight 9.50 (SD 0.42) kg) were obtained from Glenlea Swine Research Unit, University of 
Manitoba immediately after weaning, and group-housed in pens and monitored for consumption of a commercial starter diet to ensure that piglets were healthy and able to eat and hence ready for surgeries. After $3 \mathrm{~d}$, piglets were transferred to metabolic crates to adapt to the crates for $2 \mathrm{~d}$, and then surgically fitted with a simple T-cannula at the distal ileum as described by Nyachoti et al. ${ }^{(14)}$. After surgery, piglets were returned to the metabolic crates and allowed a $7 \mathrm{~d}$ recovery period before the commencement of the experiment. During the recovery period, they were fed twice daily increasing amounts of the starter diet starting with $50 \mathrm{~g}$ of the feed after surgery and then increasing the amount offered by $50 \mathrm{~g} / \mathrm{d}$ until feed consumption was at 2.6 times maintenance energy requirement ${ }^{(15)}$ based on their body weight. Piglets had unlimited access to water throughout the study. The mean body weight at the start of the experiment was 10.9 (SD 0.48$) \mathrm{kg}$. The use of animals in the present study was reviewed and approved by the University of Manitoba Animal Care Protocol Management and Review Committee (Protocol no. F05-001/1/2), and piglets were handled in accordance with the guidelines described by the Canadian Council on Animal Care ${ }^{(16)}$.

\section{Diets}

During the experimental period, four casein-maize starchbased diets formulated to meet National Research Council ${ }^{(17)}$ energy, essential AA, vitamin and mineral requirements for piglets (Table 1) were fed. The diets included a control diet either unsupplemented or supplemented with 5,10 or $20 \mathrm{~g} / \mathrm{kg}$ PA (as sodium phytate; Sigma-Aldrich Corporation, St Louis, MO, USA). Two sets of four diets were prepared: one set of diets contained chromic oxide $(3 \mathrm{~g} / \mathrm{kg})$ as an indigestible marker and intact casein; whereas the other set contained titanium oxide $(3 \mathrm{~g} / \mathrm{kg})$ as an indigestible marker and $50 \%$ of the dietary casein was guanidinated to convert lysine to homoarginine for determination of endogenous AA flow at the terminal ileum by the homoarginine method ${ }^{(12)}$. Casein was guanidinated as described by Nyachoti et al. ${ }^{(14,18)}$.

\section{Experimental design and procedure}

The experiment was conducted as a $4 \times 4$ Latin square design combined with a $4 \times 3$ Youden square design to give seven replicates per diet. Each period lasted for $7 \mathrm{~d}$. Piglets were fed their respective un-guanidinated diets during the first $6 \mathrm{~d}$ and guanidinated diets during day 7 of each period. On days 5 and 6 , ileal digesta was collected continuously from each pig from 08.00 to 20.00 hours daily and stored frozen at $-20^{\circ} \mathrm{C}$ for later determination of apparent ileal nutrient digestibility. On day 7, ileal digesta was collected continuously from 12.00 hours (when the chromic oxide (green colour) from un-guanidinated diets had disappeared from the digesta) to 10.00 hours the following day (before the appearance of chromic oxide from un-guanidinated diets fed on the same day at 08.00 hours) and similarly stored frozen for later determination of endogenous AA flow at the terminal ileum and true ileal digestibility (TID) of AA. During the experiment, pigs were fed the four experimental diets at 2.6 times maintenance energy requirement ${ }^{(16)}$ based on their body weight at the beginning of each experimental period. The diets were offered in two equal portions at 08.00 and 15.30 hours on days 1-6 and in three equal portions at 08.00, 15.30 and 20.30 hours on day 7 .

\section{Sample preparation and chemical analyses}

The ileal digesta collected from each pig in each period were pooled for days 5 and 6 (un-guanidinated diet) and for day 7 (guanidinated diet), homogenised in a blender (Waring Commercial, Torrington, CT, USA), sub-sampled and freeze-dried. The dried ileal digesta were finely ground in a grinder (CBG5 Smart Grind; Applica Consumer Products Inc., Shelton, CT, USA), and thoroughly mixed prior to analysis.

Diet and digesta DM content was determined according to Association of Official Analytical Chemists procedures (Procedure $4.1 .06^{(19)}$ ), and $\mathrm{N}$ was determined using a $\mathrm{N}$ analyser (Model NS-2000; LECO Corporation, St. Joseph, MI, USA). Samples for $\mathrm{Ca}, \mathrm{P}, \mathrm{K}, \mathrm{Na}$ and $\mathrm{Mg}$ analyses were ashed for $24 \mathrm{~h}$ and digested according to Association of Official

Table 1. Composition of basal diet as fed basis*

\begin{tabular}{|c|c|}
\hline Ingredient & Amount $(\mathrm{g} / \mathrm{kg})$ \\
\hline Maize starch & $486 \cdot 0$ \\
\hline Lactose & $200 \cdot 0$ \\
\hline Casein & $200 \cdot 0$ \\
\hline Vegetable oil & $30 \cdot 0$ \\
\hline Cellulose & $30 \cdot 0$ \\
\hline Monocalcium phosphate & $13 \cdot 0$ \\
\hline Limestone & $13 \cdot 0$ \\
\hline Salt & $5 \cdot 0$ \\
\hline Potassium carbonate & $4 \cdot 0$ \\
\hline Magnesium oxide & 1.0 \\
\hline Marker† & 3.0 \\
\hline Vitamin/mineral premix $\ddagger$ & $15 \cdot 0$ \\
\hline \multicolumn{2}{|l|}{ Calculated nutrient content§ } \\
\hline Digestible energy (MJ/kg) & $15 \cdot 2$ \\
\hline Crude protein $(\mathrm{g} / \mathrm{kg})$ & $177 \cdot 4$ \\
\hline $\mathrm{Ca}(\mathrm{g} / \mathrm{kg})$ & 8.57 \\
\hline Total P $(\mathrm{g} / \mathrm{kg})$ & $4 \cdot 37$ \\
\hline Available $P(\mathrm{~g} / \mathrm{kg})$ & $4 \cdot 24$ \\
\hline \multicolumn{2}{|c|}{ Digestible amino acids content $(\mathrm{g} / \mathrm{kg})$} \\
\hline Lysine & $14 \cdot 0$ \\
\hline Methionine & $5 \cdot 2$ \\
\hline Threonine & $7 \cdot 0$ \\
\hline \multicolumn{2}{|l|}{ Analysed nutrient content $\|$} \\
\hline Crude protein $(\mathrm{g} / \mathrm{kg})$ & $177 \cdot 1$ \\
\hline $\mathrm{Ca}(\mathrm{g} / \mathrm{kg})$ & $9 \cdot 43$ \\
\hline Total P (g/kg) & 5.02 \\
\hline \multicolumn{2}{|c|}{ Digestible amino acids content $(\mathrm{g} / \mathrm{kg})$} \\
\hline Lysine & $13 \cdot 7$ \\
\hline Methionine & $7 \cdot 70$ \\
\hline Threonine & 8.43 \\
\hline
\end{tabular}

* The basal diet was prepared in two sets; in one set, all the casein was intact, whereas in the other set, $50 \%$ of casein in diet had been guanidinated.

†Chromic oxide was used as an indigestibility marker in un-guanidinated diet, whereas titanium oxide was used as an indigestibility marker in guanidinated diet.

¥Vitamin/mineral premix supplied the following per $\mathrm{kg}$ of finished diet: retinol, $2479 \mu \mathrm{g}$; cholecalciferol, $25 \mu \mathrm{g} ; \alpha$-tocopherol, $13.4 \mathrm{mg}$; phylloquinone, $1.1 \mathrm{mg}$ riboflavin, $5 \mathrm{mg}$; nicotinamide, $36.8 \mathrm{mg}$; cyanocobalamin, $25 \mathrm{mg}$; pyridoxine, $4.4 \mathrm{mg}$; biotin, $200 \mathrm{mg}$; pteroyl(mono)glutamic acid, $1 \mathrm{mg}$; choline, $781 \mathrm{mg}$; copper, $6 \mathrm{mg}$; iodine, $0.28 \mathrm{mg}$; iron, $100 \mathrm{mg}$; manganese, 40 ; selenium, $0.30 \mathrm{mg}$; zinc, $100 \mathrm{mg}$.

$\S$ Based on ingredient composition data by the National Research Council ${ }^{(17)}$

|| Performed on un-guanidinated diet. 
Analytical Chemists ${ }^{(20)}$ procedures (method 990.08) and read on a Varian Inductively Coupled Plasma Mass Spectrometer (Varian Inc., Palo Alto, CA, USA). Samples for AA analysis were prepared by acid hydrolysis according to Association of Official Analytical Chemists procedures (Procedure 4.1.11 alternative $3^{(19)}$ ). Samples for analysis of sulphur-containing AA (methionine and cysteine) were subjected to performic acid oxidation prior to acid hydrolysis. Tryptophan was not determined. Samples for $\mathrm{Cr}$ analysis were ashed and digested according to procedures described by William et al. ${ }^{(21)}$ and read on a Varian Inductively Coupled Plasma Mass Spectrometer. Titanium was determined according to the method of Myers et al. ${ }^{(22)}$.

\section{Calculations and statistical analysis}

The extent of conversion of lysine to homoarginine was calculated as described by Nyachoti et al. ${ }^{(14)}$. Apparent ileal DM, mineral and AA digestibilities, and TID of AA and endogenous AA flow at the terminal ileum were calculated as described by Nyachoti et al. ${ }^{(18)}$. Data obtained were subjected to ANOVA as a $4 \times 4$ Latin square design ${ }^{(23)}$ combined with a $4 \times 3$ Youden square design ${ }^{(23)}$ with $6 \mathrm{df}$ for piglets, $3 \mathrm{df}$ for periods, $3 \mathrm{df}$ for diets and $15 \mathrm{df}$ for the error term using Mixed procedure (SAS software release 9.1; SAS Institute, Cary, NC, USA). Linear and quadratic contrasts for unequally spaced levels ${ }^{(24)}$ were performed to assess the effect of increasing dietary concentration of PA.

\section{Results}

The extent of conversion of lysine to homoarginine in guanidinated casein was $96 \cdot 3 \%$ (data not shown). Analysed chemical composition of the basal diet is shown in Table 1. The analysed crude protein and digestible lysine contents were similar to calculated values, whereas those for $\mathrm{Ca}$ and $\mathrm{P}$ contents and digestible methionine and threonine contents were higher than the calculated values.

The effects of dietary treatment on apparent ileal digestibility (AID) of DM, Ca, Na, K, Mg and $\mathrm{P}$ are presented in Table 2. PA linearly reduced $(P<0.05)$ the AID of DM. The AID of $\mathrm{Na}, \mathrm{K}$ and $\mathrm{P}$ were linearly and quadratically reduced $(P<0.05)$ by increased dietary concentration of $\mathrm{PA}$, whereas that of $\mathrm{Ca}$ and $\mathrm{Mg}$ was only linearly reduced $(P<0.05)$ by the dietary PA. The quadratic reduction in AID of $\mathrm{P}$ was such that the decrease in the digestibility was greater when the level of PA was increased from 0 to $10 \mathrm{~g} / \mathrm{kg}$ than when it was increased from 10 to $20 \mathrm{~g} / \mathrm{kg}$. On the other hand, the quadratic reduction in AID of $\mathrm{Na}$ and $\mathrm{K}$ was such that the decrease in the digestibility of these minerals was lower when the concentration of PA was increased from 0 to $10 \mathrm{~g} / \mathrm{kg}$ than when it was increased from 10 to $20 \mathrm{~g} / \mathrm{kg}$. The AID values for $\mathrm{Na}$ and $\mathrm{K}$ were negative when PA was supplemented at $20 \mathrm{~g} / \mathrm{kg}$, with the AID value for $\mathrm{Na}$ being the lowest.

Tables 3-5 show the AID, endogenous losses and TID of AA, respectively. Increasing dietary concentration of PA resulted in a quadratic response $(P<0.05)$ in AID of isoleucine, leucine, valine, glutamic acid, proline and serine such that the AID of these AA increased when the dietary concentration of PA was increased from 0 to $10 \mathrm{~g} / \mathrm{kg}$ and then declined when the dietary PA level was further increased to
Table 2. Effect of phytic acid level on apparent ileal DM and mineral digestibility coefficients in piglets fed casein-maize starch-based diet*

\begin{tabular}{|c|c|c|c|c|c|}
\hline \multirow[b]{2}{*}{ Item } & \multicolumn{4}{|c|}{ Dietary phytic acid $(\mathrm{g} / \mathrm{kg})$} & \multirow[b]{2}{*}{ SEM } \\
\hline & 0 & 5 & 10 & 20 & \\
\hline $\mathrm{DM} \dagger$ & 0.886 & 0.881 & 0.885 & 0.862 & 0.0038 \\
\hline Ca† & 0.782 & 0.711 & 0.534 & 0.369 & 0.0166 \\
\hline Mg† & 0.291 & 0.188 & 0.137 & -0.030 & 0.0218 \\
\hline P†‡ & 0.801 & 0.654 & 0.505 & 0.372 & 0.0178 \\
\hline Na†‡ & 0.492 & 0.427 & 0.466 & -0.182 & 0.0729 \\
\hline K†‡ & 0.876 & 0.866 & 0.890 & 0.811 & 0.0131 \\
\hline
\end{tabular}

${ }^{*}$ For details of procedures, see Materials and methods.

$\dagger$ Linear effect $(P<0.05)$.

$\ddagger$ Quadratic effect $(P<0.05)$.

$20 \mathrm{~g} / \mathrm{kg}$, though the differences between the AID values of the AA at dietary PA supplementation of 0 and $10 \mathrm{~g} / \mathrm{kg}$ were marginal (on average by 1.8 percentage points). A similar trend was observed for TID of isoleucine, leucine, glutamic acid and proline when the dietary concentration of PA was increased. However, the AID and TID values of other AA, and the endogenous AA losses, were unaffected $(P>0.05)$ by the dietary concentration of PA.

\section{Discussion}

The analysed dietary $\mathrm{Ca}$ and $\mathrm{P}$ contents and digestible methionine and threonine contents were higher than the calculated values, which could probably be due to differences between the composition of the actual ingredients that were used in

Table 3. Effect of phytic acid level on apparent ileal digestibility coefficients of nitrogen and amino acids in piglets fed casein-maize starchbased diet $^{*}$

\begin{tabular}{lccccc}
\hline & \multicolumn{5}{c}{ Dietary phytic acid $(\mathrm{g} / \mathrm{kg})$} \\
\cline { 2 - 5 } Item & 0 & 5 & 10 & 20 & SEM \\
\hline Nitrogen† & 0.904 & 0.905 & 0.920 & 0.902 & 0.0045 \\
Indispensable amino acids & & & & \\
Arginine & 0.917 & 0.912 & 0.932 & 0.917 & 0.0047 \\
Histidine & 0.945 & 0.945 & 0.957 & 0.947 & 0.0034 \\
Isoleucine† & 0.933 & 0.936 & 0.951 & 0.933 & 0.0027 \\
Leucine† & 0.955 & 0.952 & 0.966 & 0.953 & 0.0028 \\
Lysine & 0.945 & 0.943 & 0.950 & 0.945 & 0.0023 \\
Methionine & 0.951 & 0.947 & 0.957 & 0.946 & 0.0024 \\
Phenylalanine & 0.956 & 0.947 & 0.964 & 0.952 & 0.0029 \\
Threonine & 0.876 & 0.866 & 0.886 & 0.868 & 0.0049 \\
Valine† & 0.920 & 0.918 & 0.930 & 0.915 & 0.0030 \\
Dispensable amino acids & 0.870 & 0.868 & 0.892 & 0.873 & 0.0056 \\
Alanine & 0.892 & 0.886 & 0.903 & 0.881 & 0.0054 \\
Aspartic acid & 0.948 & 0.938 & 0.952 & 0.946 & 0.0019 \\
Cysteine & 0.946 & 0.947 & 0.956 & 0.932 & 0.0054 \\
Glutamic acid† & 0.714 & 0.720 & 0.775 & 0.697 & 0.0234 \\
Glycine & 0.925 & 0.944 & 0.955 & 0.935 & 0.0096 \\
Proline† & 0.887 & 0.897 & 0.913 & 0.896 & 0.0065 \\
Serine† & 0.962 & 0.947 & 0.970 & 0.952 & 0.0054 \\
Tyrosine & & & & & \\
\hline
\end{tabular}

${ }^{*}$ For details of procedures, see Materials and methods.

†Quadratic effect $(P<0 \cdot 05)$. 
Table 4. Effect of phytic acid level on endogenous losses of amino acids (mg/kg DM) in piglets fed casein-maize starch-based diet ${ }^{*}$

\begin{tabular}{lrrrrr}
\hline & \multicolumn{4}{c}{ Dietary phytic acid $(\mathrm{g} / \mathrm{kg})$} & \\
\cline { 2 - 4 } Item & \multicolumn{1}{c}{5} & \multicolumn{1}{c}{5} & 10 & 20 & SEM \\
\hline Indispensable amino & acids & & & & \\
Arginine & 602 & 714 & 602 & 690 & 58 \\
Histidine & 338 & 360 & 305 & 344 & 15 \\
Isoleucine & 563 & 600 & 509 & 573 & 24 \\
Leucine & 900 & 959 & 814 & 916 & 29 \\
Lysine & 675 & 719 & 611 & 687 & 29 \\
Methionine & 225 & 240 & 204 & 229 & $9 \cdot 7$ \\
Phenylalanine & 675 & 719 & 611 & 687 & 29 \\
Threonine & 1013 & 1079 & 916 & 1030 & 44 \\
Valine & 788 & 839 & 713 & 802 & 34 \\
Dispensable amino & acids & & & & \\
Alanine & 951 & 1013 & 860 & 967 & 41 \\
Aspartic acid & 1587 & 1691 & 1435 & 1612 & 69 \\
Cysteine & 360 & 384 & 326 & 366 & 16 \\
Glutamic acid & 2251 & 2398 & 2036 & 2291 & 98 \\
Glycine & 999 & 1065 & 904 & 1017 & 43 \\
Proline & 736 & 784 & 666 & 749 & 32 \\
Serine & 1035 & 1103 & 936 & 1053 & 45 \\
Tyrosine & 450 & 480 & 407 & 458 & 20 \\
\hline
\end{tabular}

${ }^{*}$ For details of procedures, see Materials and methods.

the present study and the values given by the National Research Council $^{(17)}$ for the same ingredients. The differences between the analysed dietary digestible methionine and threonine contents might also have been due to cumulative error during the analysis because the differences between the analysed and calculated values for crude protein and lysine were minimal.

PA has been shown to reduce AID of cationic minerals in pigs $^{(10)}$ and broilers ${ }^{(4)}$, which is consistent with current observations. In the current study, however, PA supplementation at

Table 5. Effect of phytic acid level on true ileal amino acid and nitrogen digestibility coefficients in piglets fed casein-maize starch-based diet*

\begin{tabular}{|c|c|c|c|c|c|}
\hline \multirow[b]{2}{*}{ Item } & \multicolumn{4}{|c|}{ Dietary phytic acid $(\mathrm{g} / \mathrm{kg})$} & \multirow[b]{2}{*}{ SEM } \\
\hline & 0 & 5 & 10 & 20 & \\
\hline Nitrogen† & 0.922 & 0.922 & 0.935 & 0.920 & 0.0037 \\
\hline \multicolumn{6}{|c|}{ Indispensable amino acids } \\
\hline Arginine & 1.030 & 1.032 & 1.034 & 1.032 & 0.0024 \\
\hline Histidine† & 1.015 & 1.019 & 1.020 & 1.109 & 0.0013 \\
\hline Isoleucine† & 0.993 & 0.999 & 1.006 & 0.994 & 0.0025 \\
\hline Leucine† & 1.006 & 1.006 & 1.012 & 1.005 & 0.0015 \\
\hline Lysine & 0.993 & 0.994 & 0.994 & 0.994 & 0.0007 \\
\hline Methionine & 0.986 & 0.985 & 0.990 & 0.982 & 0.0017 \\
\hline Phenylalanine & 1.025 & 1.024 & 1.027 & 1.023 & 0.0015 \\
\hline Threonine & 0.993 & 0.991 & 0.992 & 0.988 & 0.0042 \\
\hline Valine & 0.985 & 0.988 & 0.989 & 0.982 & 0.0024 \\
\hline \multicolumn{6}{|c|}{ Dispensable amino acids } \\
\hline Alanine & 1.044 & 1.054 & 1.050 & 1.051 & 0.0051 \\
\hline Aspartic acid & 1.013 & 1.015 & 1.013 & 1.004 & 0.0038 \\
\hline Cysteine & $1 \cdot 227$ & 1.236 & 1.205 & 1.231 & 0.012 \\
\hline Glutamic acid $\dagger$ & 0.998 & 1.003 & 1.003 & 0.985 & 0.0047 \\
\hline Glycine & 0.983 & 1.006 & 1.018 & 0.971 & 0.0177 \\
\hline Proline† & 0.958 & 0.980 & 0.985 & 0.969 & 0.0094 \\
\hline Serine & 0.986 & 1.003 & 1.003 & 0.997 & 0.0057 \\
\hline Tyrosine & 1.016 & 1.005 & 1.019 & 1.005 & 0.0046 \\
\hline
\end{tabular}

${ }^{*}$ For details of procedures, see Materials and methods.

†Quadratic effect $(P<0.05)$.
$20 \mathrm{~g} / \mathrm{kg}$ resulted in negative AID values of $\mathrm{Na}$ and $\mathrm{Mg}$, indicating increased endogenous flow of these minerals at the terminal ileum due to PA. Cowieson et al. ${ }^{(7)}$ also observed increased excretion of endogenous minerals in broilers due to PA. In both the present study and that of Cowieson et al. ${ }^{(7)}$, Na was the most affected mineral. Sodium deficiency in chickens has been reported to reduce the activity of intestinal Na-K-ATPase in the gut, which is involved in the absorption of glucose and other nutrients ${ }^{(25)}$. Thus, the increase in endogenous secretion of minerals such as Na due to PA may have significant nutritional and physiological implications as it could result in alteration of electrolyte balance and hence Na-K-ATPase activity and nutrient absorption in the small intestine. This is supported by results from a broiler study by Liu et al. ${ }^{(26)}$ which showed reduced activity of Na-KATPase in broilers due to ingestion of PA. However, in pigs unlike in poultry, the minerals that are endogenously secreted in the small intestine may be re-absorbed in the large intestine. Hence, the alteration in the electrolyte balance due to PA might be local (in the mucosa of the small intestine), but not systemic (in the whole body) as the deficiency of the minerals would be corrected by re-absorption in the large intestine. It will be interesting to see the effects of PA on $\mathrm{Na}$ retention in the body, and on the activity of Na-K-ATPase and nutrient absorption in the small intestine.

The mechanisms by which PA increases the endogenous secretion of minerals in the gastrointestinal tract have not yet been established. However, two mechanisms are proposed. First, PA may bind to enzyme co-factors in the gut, resulting in increased mineral secretion through negative feedback mechanisms. Second, amino groups found on side-chains of basic AA and at amino terminal ends of proteins possess a net positive charge at $\mathrm{pH}$ below the isoelectric point ${ }^{(27)}$. Hence PA may interact with dietary protein, and endogenous protein (pepsin, and pepsinogen and its activating peptide) in the stomach, where the $\mathrm{pH}$ is $\operatorname{acidic}^{(7)}$, thereby reducing the activity of pepsin and hence increasing the secretion of the enzyme and $\mathrm{HCl}$ via negative feedback mechanisms ${ }^{(5)}$. The resulting acidic digesta may then need to be neutralised in the small intestine by mineral-bicarbonates secreted by the intestine $^{(28)}$ and pancreas ${ }^{(29)}$ to protect small intestinal mucosa from acid digestion and to optimise pancreatic and intestinal digestive enzymes, resulting in increased endogenous secretion and hence losses of the minerals. Because pancreatic juice is richer in $\mathrm{Na}$ than other minerals ${ }^{(29)}$ and it is $\mathrm{Na}$ that was most affected by PA, it appears that PA increases the endogenous losses of minerals (especially $\mathrm{Na}$ ) mainly by increasing the endogenous secretion of mineral-bicarbonates in the small intestine to neutralise the acidic digesta exiting the stomach. This hypothesis, however, needs to be proven.

In the current study, the reduction in AID of monovalent cations ( $\mathrm{Na}$ and $\mathrm{K}$ ) due to increased dietary concentration of PA was quadratic such that the reduction in AID of these cations was lower when the dietary PA level was increased from 0 to $10 \mathrm{~g} / \mathrm{kg}$, than when it was increased from 10 to $20 \mathrm{~g} / \mathrm{kg}$. On the other hand, the reduction in AID of divalent cations ( $\mathrm{Ca}$ and $\mathrm{Mg}$ ) due to dietary PA was linear such that the magnitude by which dietary PA reduced the AID of these cations did not change when the level of PA was increased from 0 to $10 \mathrm{~g} / \mathrm{kg}$ or from 10 to $20 \mathrm{~g} / \mathrm{kg}$. PA is known to form weaker bonds with monovalent cations than with divalent cations ${ }^{(30)}$. 
This implies that the reduction in AID of cations due to their binding to dietary PA could be more for divalent than monovalent cations. Therefore, the different responses in the AID of monovalent cations compared with that of their divalent counterparts (due to increasing level of dietary PA) could probably be due to differences in mechanisms by which PA reduces the AID of the two categories of cations (monovalent versus divalent).

PA supplementation reduced the AID of $\mathrm{P}$ in the current study. This is interesting because $\mathrm{P}$, unlike other minerals whose AID was measured in the current study, is negatively charged. The reduced AID of P due to PA could have been due to binding of PA to both endogenous and dietary non$\mathrm{PA} P$ via divalent cations to form $\mathrm{PA}-$ cation $-\mathrm{P}$ complexes. Because the true digestibility of $\mathrm{P}$ in pigs is lower for diets with higher PA concentration than for those with lower concentration of the same ${ }^{(31)}$, the lower AID of P due to PA could also have been as a result of higher content of PAbound P in PA-supplemented diets. It is, however, not clear why the decrease in AID of $\mathrm{P}$, in contrast to that of other minerals measured in the present study, was greater when the level of PA was increased from 0 to $10 \mathrm{~g} / \mathrm{kg}$ than when it was increased from 10 to $20 \mathrm{~g} / \mathrm{kg}$.

The rate of conversion of lysine into homoarginine in casein $(96.3 \%)$ was within the range of values reported by Nyachoti et al. ${ }^{(14)}(89.2 \%)$ and Schmitz et al. ${ }^{(32)}$ (99.6\%). The AID, endogenous losses and TID of AA observed in the current study were generally similar to what Nyachoti et al. ${ }^{(18)}$ reported in growing pigs fed casein-maize starch with casein content $(20 \%)$ that is similar to what was contained in the basal diet used in the current study.

In addition to reducing mineral digestibility, PA is expected to bind to AA in the diet and proteolytic enzymes ${ }^{(7)}$, resulting in reduced true AA digestibility. Also by interacting with AA in both diet and proteolytic enzymes in the stomach, PA is expected to increase enzyme and $\mathrm{HCl}$ secretion as previously discussed. Also, PA could bind to enzymes secreted by pancreas and small intestinal wall, resulting in their compensatory secretion. Because one of the physiological functions of mucin is to protect the gut wall from degradation by acid and proteolytic enzymes ${ }^{(33)}$, the increased proteolytic enzymes and $\mathrm{HCl}$ secretion is expected to result in increased mucin secretion to protect the gut wall from the enzyme and acid digestion, resulting in increased endogenous losses of AA and $\mathrm{N}$ contained in the digestive enzyme and mucin. Thus, the presence of PA in pig diets is expected to result in reduced TID and increased endogenous losses of $\mathrm{AA}$, and hence decreased AID of the same. In the current study, however, PA supplementation did not decrease the AID and TID of AA and promote the endogenous losses of the same. This observation contradicts results of Bohlke et al. ${ }^{(10)}$ and Liao et al. ${ }^{(11)}$, who reported decreased AID of AA due to PA. Results of the current study, however, are similar to those of studies that did not report reduced AA digestibility in pigs due to phytase (which hydrolyses PA) despite increased PA hydrolysis as evidenced by improved $\mathrm{P}$ digestibility ${ }^{(12,13)}$. It is not clear why PA has variable effects on AA digestibility in pigs.

Naturally, PA occurs as a mixed salt of cations, mainly $\mathrm{K}$ and $\mathrm{Mg}$, and to a lesser extent $\mathrm{Ca}, \mathrm{Fe}$ and $\mathrm{Zn}$ in spherical inclusions called globoids within protein bodies ${ }^{(34-37)}$. In most feed ingredients, PA is concentrated within cells that are rich in fibre ${ }^{(34,35)}$. Thus, in order to determine the actual effect of PA on nutrient utilisation, PA-free diet should be fed with and without PA in a fibre-free form because fibre also affects the digestibility and endogenous losses of nutrients. It was, however, difficult to get PA in a form that is naturally found in feed ingredients (mixed salt of cations) in the market. Most of the PA products that were available in the market at time when the study was conducted are salts of one cation and hence the reason why sodium phytate was used in the current study. Nonetheless, in pigs, the mode of action of intrinsic PA is expected to be the same as that used in the present study due to the following two reasons. First, PA and the cationic minerals disassociate at acidic $\mathrm{pH}$ found in the stomach because they are both soluble at this $\mathrm{pH}^{(1)}$. Therefore, the form in which PA exerts its effects in the stomach is independent of the original form in which it is supplied in the diet. Second, at small intestinal $\mathrm{pH}, \mathrm{PA}$ reacts with free cationic minerals to form phytate ${ }^{(1)}$. The major cationic mineral in practical diets is Ca. Therefore, $\mathrm{PA}$ is likely to complex more $\mathrm{Ca}$ than other cations regardless of its original form in the diet. It should, however, be noted that the $\mathrm{pH}$ in the crop of poultry is not acidic enough to cause disassociation between PA and cationic minerals, and therefore, PA may exert its effects in the crop in a form that is similar to the form that it is supplied in the diet, resulting in an overall influence of dietary form of PA on response to its ingestion.

In conclusion, the results suggest that dietary PA has limited effect on the digestibility and endogenous losses of AA, but can reduce apparent ileal mineral digestibility in piglets partly due to their increased endogenous secretion at the terminal ileum as evidenced by negative AID values for some minerals. The increase in endogenous flow of minerals such as Na may be particularly important as an increased presence of these minerals in the gut will effectively alter electrolyte balance. The altered electrolyte balance may result in reduced activity of $\mathrm{Na}-\mathrm{K}$ ATPase and hence the capacity of the enterocytes to transport glucose and other nutrients. The present data are thus suggestive of important physiological responses in piglets to the ingestion of PA.

\section{Acknowledgements}

The research was conducted at the University of Manitoba. The authors thank R. Stuski for assistance with animal care and Dr G. Crow for statistical consulting. This work was supported by Manitoba Pork Council through its strategic research funding to the Department of Animal Science, University of Manitoba. None of the authors had any conflict of interest. T. A. W. designed and conducted the study, analysed data and prepared the first draft of the manuscript. A. J. C. and O. A. critically reviewed the experimental protocol and the manuscript, whereas C. M. N. provided overall direction for the study and manuscript preparation.

\section{References}

1. Maenz DD (2001) Enzymatic and other characteristics of phytases as they relate to their use in animal feeds. In Enzymes in Farm Animal Nutrition, pp. 61-84 [MR Bedford and GG Partridge, editors]. Wallingford, UK: CABI Publishing. 
2. Bedford MR (2000) Exogenous enzymes in monogastric nutrition - their current value and future benefits. Anim Feed $S c i$ Technol 86, 1-13.

3. Ravindran V, Cabahug S, Ravindran G, et al. (2000) Response of broiler chickens to microbial phytase supplementation as influenced by dietary phytic acid and non-phytate phosphorous levels. II. Effects on apparent metabolisable energy, nutrient digestibility and nutrient retention. Br Poult Sci 41, 193-200.

4. Ravindran V, Morel PCH, Partridge GG, et al. (2006) Influence of an Escherichia coli-derived phytase on nutrient utilization in broiler starters fed diets containing varying concentrations of phytic acid. Poult Sci 85, 82-89.

5. Cowieson AJ, Acamovic T \& Bedford MR (2006) Phytic acid and phytase: implication for protein utilisation by poultry. Poult Sci 85, 878-885.

6. Lenis NP \& Jongbloed AW (1999) New technologies in low pollution swine diets: diet manipulation and use of synthetic amino acids, phytase and phase feeding for reduction of nitrogen and phosphorus excretion and ammonia emission review. Asian Aust J Anim Sci 12, 305-327.

7. Cowieson AJ, Acamovic T \& Bedford MR (2004) The effects of phytase and phytic acid on the loss of endogenous amino acids and minerals from broiler chickens. Br Poult Sci 45, $101-108$

8. Cowieson AJ \& Ravindran V (2007) Effect of phytic acid and microbial phytase on the flow and amino acid composition of endogenous protein at the terminal ileum of growing broiler chickens. Br J Nutr 98, 745-752.

9. Nyachoti CM, de Lange CFM, McBride BW, et al. (1997) Significance of endogenous gut nitrogen losses in the nutrition of growing pigs: a review. Can J Anim Sci 77, 149-163.

10. Bohlke RA, Thaler RC \& Stein HH (2005) Calcium, phosphorus, and amino acid digestibility in low-phytate corn, normal corn, and soybean meal by growing pigs. J Anim Sci 83, 2396-2403.

11. Liao SF, Kies AK, Sauer WC, et al. (2005) Effect of phytase supplementation to a low- and a high-phytate diet for growing pigs on the digestibilities of crude protein, amino acids, and energy. J Anim Sci 83, 2130-2136.

12. Johnston SL, Williams SB, Southern LL, et al. (2004) Effect of phytase addition and dietary calcium and phosphorus levels on plasma metabolites and ileal and total-tract nutrient digestibility in pigs. J Anim Sci 82, 705-714.

13. Woyengo TA, Sands JS, Guenter W, et al. (2008) Nutrient digestibility and performance responses of growing pigs fed phytase- and xylanase-supplemented wheat-based diets. J Anim Sci 86, 848-857.

14. Nyachoti CM, McNeilage-Van de Wiele EM, de Lange CFM, et al. (2002) Evaluation of the homoarginine technique for measuring true ileal amino acid digestibilities in pigs fed a barley-canola meal-based diet. J Anim Sci 80, 440-448.

15. Agricultural Research Council (1981) The Nutrient Requirements of Pigs. Slough, UK: Agricultural Research Council.

16. Canadian Council on Animal Care (1993) Guide to the Care and Use of Experimental Animals. Ottawa: Canadian Council on Animal Care.

17. National Research Council (1998) Nutrient Requirements of Swine. Washington, DC: National Academy Press.

18. Nyachoti CM, de Lange CFM \& Schulze H (1997) Estimating endogenous amino acid flows at the terminal ileum and true ileal amino acid digestibilities in feedstuffs for growing pigs using the homoarginine method. J Anim Sci 75, 3206-3213.
19. Association of Official Analytical Chemists (1998) Official Methods of Analysis. Washington, DC: Association of Official Analytical Chemists.

20. Association of Official Analytical Chemists (1990) Official Methods of Analysis. Washington, DC: Association of Official Analytical Chemists.

21. William CH, David DJ \& Iismaa O (1962) The determination of chromic oxide in fecal samples by atomic absorption spectrophotometry. J Agric Sci 59, 381-385.

22. Myers WD, Ludden PA, Nayigihugu V, et al. (2004) Technical note: a procedure for the preparation and quantitative analysis of samples for titanium dioxide. J Anim Sci 82, 179-183.

23. Cochran WG \& Cox GM (1957) Experimental Designs, 2nd ed. New York: John Wiley \& Sons.

24. Gill JL (1978) Design and Analysis of Experiments in the Animal and Medical Sciences, vol. 3. Ames: The Iowa State University Press.

25. Gal-Garber O, Mabjeesh SJ, Sklan D, et al. (2003) Nutrient transport in the small intestine: $\mathrm{Na}^{+}, \mathrm{K}^{+}$-ATPase expression and activity in the small intestine of the chicken as influenced by dietary sodium. Poult Sci 82, 1127-1133.

26. Liu N, Ru YJ, Li FD, et al. (2008) Effect of diet containing phytate and phytase on the activity and messenger ribonucleic acid expression of carbohydrase and transporter in chickens. J Anim Sci 86, 3432-3439.

27. Hídvégi M \& Lásztity R (2002) Phytic acid content of cereals and legumes and interaction with proteins. Periodica Polytechnica Ser Chem Eng 46, 59-64.

28. Allen A, Flemstrom G, Garner A, et al. (1993) Gastroduodenal mucosal protection. Physiol Rev 73, 823-857.

29. Zebrowska T, Low AG \& Zebrowska H (1983) Studies on gastric digestion of protein and carbohydrate, gastric secretion and exocrine pancreatic secretion in the growing pig. Br J Nutr 49, 401-410.

30. Erdman JW Jr (1979) Oilseed phytates: nutritional implications. $J$ Am Oil Chem Soc 56, 736-741.

31. Dilger RN \& Adeola O (2006) Estimation of true phosphorus digestibility and endogenous phosphorus loss in growing pigs fed conventional and low-phytate soybean meals. J Anim Sci 84, 627-634.

32. Schmitz M, Hagemeister H \& Erbersdobler HF (1991) Homoarginine labelling is suitable for determination of protein absorption in miniature pigs. $J$ Nutr 121, 1575-1580.

33. Montagne L, Piel C \& Lalles JP (2004) Effect of diet on mucin kinetics and composition: nutrition and health implications. Nutr Rev 62, 105-114.

34. Ockenden I, Dorsch JA, Reid MM, et al. (2004) Characterization of the storage of phosphorus, inositol phosphate and cations in grain tissues of four barley (Hordeum vulgare L.) low phytic acid genotypes. Plant Sci 167, 1131-1142.

35. Joyce C, Deneau A, Peterson K, et al. (2005) The concentrations and distributions of phytic acid phosphorus and other mineral nutrients in wild-type and low phytic acid Js-12-LPA wheat (Triticum aestivum) grain parts. Can J Bot 83, 1599-1607.

36. Lin L, Ockenden I \& Lott JNA (2005) The concentrations and distributions of phytic acid phosphorus and other mineral nutrients in wild-type and low phytic acid 1-1 (lpa1-1) corn (Zea mays L.) grain parts. Can J Bot 83, 131-141.

37. Prattley CA \& Stanely DW (1982) Protein-phytate interactions in soybeans. I. Localisation of phytate in protein bodies and globoids. J Food Biochem 6, 243-253. 